\title{
PENINGKATAN KARAKTER SISWA MELALUI PENGEMBANGAN BUKU AJAR BAHASA INGGRIS INTERAKTIF BERBASIS NILAI-NILAI BUDAYA BANGSA
}

\author{
Marsuki, Yahmun, Boby Ardiyanzah Efendy
}

\author{
Email: marsukigani@yahoo.com \\ IKIP Budi Utomo Malang Jawa Timur \\ Alamat Korespondensi: IKIP Budi Utomo Malang Jawa Timur
}

\begin{abstract}
The study aims at developing a nation character and culture values-based interactive English textbook and examining its effectivity for the elementary school students in Malang. The development and experiment designs are used and the subjects consist of experts and target. The expert is an expert in instructional materials and multimedia, while the target is students of the sixth grade Elementary School Dinoyo IV Malang which totals 40 students. The true experiment design, pretestposttest control group is used by random sampling technique to obtain experiment and control groups, each of which consists of 20 students. The instruments are questionnaire, interview, and test. Based on the data analysis, it was found that the interactive English textbook fulfilled good criteria of textbook in either material coverage and selection or multimedia application. The positive responses of the students and teachers indicated good quality of textbook in improving students' competences in English. Through statistical test, it was found t result (5.93) was bigger than $t_{\text {table }}(1.310)$ in level of significance 0.01 and (1.697) in level of significance 0.05. It means that Ha which states "The students of class VIB Elementary School Dinoyo IV Malang who were taught using the nation character and culture values-based interactive English textbook, had better English competences than those of class VIA who were taught using manual English textbook" was accepted, while $\mathrm{H}_{0}$ was rejected. Therefore, it can be concluded that the use of the textbook is very effective in improving the students English competences of Elementary School in Malang.
\end{abstract}

Keywords: character, textbook, English, interactive, effective

\section{PENDAHULUAN}

Seiring dengan berlakunya kurikulum 2013 sebagai pengembangan kurikulum KTSP 2006, pendidikan budaya dan karakter bangsa di semua jenjang pendidikan mendapatkan prioritas dan porsi yang lebih maksimal dan semakin dimantapkannya implementasinya daripada sebelumnya. Nilai-nilai budaya dan karakter bangsa dalam kurikulum baru ini terlihat jelas terwujud dan terjabar dalam standar isi kurikulum (SI) yang terdiri dari standar kompetensi lulusan (SKL), kompetensi isi (KI) dan kompetensi dasar (KD) pada setiap mata pelajaran. Oleh karena itu, penanaman nilai-nilai budaya dan karakter bangsa dalam pendidikan merupakan pilar penyangga demi tegaknya pendidikan di Indonesia. Persoalan budaya dan karakter bangsa tersebut kini menjadi sorotan tajam masyarakat di berbagai aspek kehidupan baik di keluarga, sekolah dan masyarakat. Pembangunan karakter melalui pendidikan budaya dan karakter bangsa sebagai amanah dari Pancasila dan UUD 1945 merupakan salah satu progam prioritas pembangunan nasional yang tertuang dalam Rencana Pembangunan Jangka Panjang Nasional (RPJPN) dalam tahun 2005-2025.

Pengintegrasian nilai-nilai budaya dan karakter bangsa dilakukan melalui pengembangan buku ajar bahasa Inggris interaktif karena dilatarbelakangi oleh 
persoalan-persoalan karakter bangsa. Banyak kasus kenakalan yang dilakukan oleh siswa dari SD hingga SMA dewasa ini yang selalu menghiasi berita di media elektronik maupun cetak dengan kasus yang bervariasi (Marsuki, 2013, h. 10). Selain itu, dalam penelitian yang dilakukan oleh Akbar di 75 SD di Jawa Timur ditemukan bahwa perilaku moral yang sangat tidak dan kurang diharapkan dari siswa SD di Jawa Timur itu mengarah pada perilakuperilaku seperti (1) terlambat masuk sekolah, (2) tidak mengerjakan PR, (3) berbicara keraskeras, (4) marah-marah pada teman, (5) premanisme, (6) berkelahi, (7) mengolok-olok teman, (8) membantu teman berkelahi, (9) corat-coret kamar mandi dan WC sekolah, (10) merusak fasilitas sekolah, (11) kurang membaur dengan teman, (12) menghina teman, (13) tidak mengenakan seragam sekolah, (14) membuang sampah sembarangan, dan (15) kebiasaan menyontek (Akbar, 2009). Pengintegrasian pendidikan ini sebagai amanah dari Pancasila dan UUD 1945 harus dilakukan oleh setiap satuan pendidikan demi mengatasi permasalahan bangsa yang sedang berkembang saat ini seperti disorientasi dan belum dipahaminya nilai-nilai Pancasila, keterbatasan perangkat kebijakan terpadu dalam mewujudkan nilai-nilai Pancasila, bergesernya nilai-nilai etika dalam berbangsa dan bernegara, memudarnya kesadaran dalam nilai-nilai budaya bangsa, ancaman disintegrasi bangsa, dan melemahnya kemandirian bangsa (Supinah, 2011).

Berdasarkan deskripsi di atas, penelitian ini bertujuan memperoleh model buku ajar bahasa Inggris interaktif berbasis nilai-nilai budaya dan karakter bangsa serta menguji efektivitasnya dalam meningkatkan kemampuan dan keterampilan bahasa Inggris bagi siswa kelas VI SDN Dinoyo IV Kota Malang.

\section{TINJAUAN PUSTAKA \\ Pembelajaran Bahasa Inggris di Sekolah Dasar}

Mata pelajaran bahasa Inggris khususnya di sekolah dasar negeri sudah dilaksanakan selama kurang lebih 18 tahun yang lalu.Pelaksanaan ini dilandasi oleh kebijakan resmi dari Depdikbud RI No.0487/4/1992, Bab VIII, yang menyatakan bahwa sekolah dasar dapat menambah matapelajaran dalam kurikulumnya, asalkan pelajaran itu tidak bertentangan dengan tujuan nasional. Kemudian, kebijakan ini disusul oleh SK Menteri Pendidikan dan Kebudayaan No. 060/U/1993 tanggal 25 Februari 1993 tentang program bahasa Inggris sebagai matapelajaran muatan lokal SD, dan dapat dimulai pada kelas 4 SD. Kemudian kebijakan nasional ini ditindaklanjuti dengan SK Kepala Kantor Wilayah Departemen Pendidikan dan Kebudayaan Propinsi Jawa Timur No. 1702/05/1994 tanggal 30 Maret 1994 yang menyatakan bahwa matapelajaran bahasa Inggris sebagai matapelajaran muatan lokal pilihan di Jawa Timur (Suyanto, 2004).

Pembelajaran bahasa asing untuk sekolah dasar di luar negeri sudah dimulai tahun 50-an, mencapai puncaknya pada tahun 60 -an dan sempat mengalami surut. Namun sekarang sejak tahun 90-an telah terjadi ledakan anak belajar bahasa asing lebih dini. Bahasa Inggris di SD sebenarnya untuk memperkenalkan kepada siswa bahwa ada bahasa lain selain bahasa ibu. Seiring diberlakukannya kurikulum 2013 terdapat perubahan tentang status bahasa Inggris yang diajarkan di SD. Berdasarkan survei kami ke sekolah pada penelitian tahap 1 bahwa secara perlahan-lahan bahasa Inggris di SD memang akan menjadi kegiatan Ekstrakurikuler. Untuk tahun ajaran 2013-2014, bahasa Inggris sebagai ekstrakurikuler telah diterapkan di kelas 1 dan 4, sedangkan kelas, 2, 3, 5, dan 6 kebijakannya masih mengikuti kurikulum KTSP 2006. Namun demikian selama ini banyak sekolah dasar (SD) menganggap pelajaran bahasa Inggris sangat penting sehingga memperlakukannya sama antara sebagai ekstrakurikuler dan mutan lokal (Marsuki, 2003). Berdasarkan kebijakankebijakan yang telah dijelaskan di atas, mata pelajaran bahasa Inggris seyogyanya diperkenalkan kepada siswa SD melalui kegiatan-kegiatan yang menarik, menyenagkan, dan interaktif sesuai dengan perkembangan jiwa dan mental mereka baik melalui pengembangan buku ajar maupun metode pembelajarannya sebagai mata pelajaran ataupun kegiatan ekstrakurikuler.

\section{Landasan Teori Pembelajaran Bahasa Inggris di SD}


Dua teori belajar yang banyak dihubung-hubungkan dengan perkembangan anak adalah teori belajar Jean Piaget dan Vygotsky. Bertolak dari teori-teori, perbincangan tentang perkembangan mental anak khususnya dalam belajar bahasa selalu menghiasi tulisan-tulisan karya ilmiah dan laporan penelitian. Terkait dengan perkembangan anak, Jean Piaget membagi empat tahapan perkembangan yaitu sensorimo stage (lahir sampai usia 2 tahun); preoperational stage (2-8 tahun); concrete operational stage (8-11 tahun); dan formal stage (11-15 tahun keatas). Jadi apabila anak SD belajar bahasa mulai 3 atau 4 mereka sedang dalam tahap concrete operational stage dan oleh karena itu mereka memerlukan banyak ilustrasi, model, gambar, dan kegiatankegiatan yang interaktif dan menyenangkan.

Oleh karena itu, Jean Piaget dan Vygotsky menyatakan bahwa pembelajaran bahasa untuk anak harus disesuaikan dengan perkembangan mental anak. Apabila seorang anak tidak dapat memahami sesuatu maka menurut Piaget anak itu belum siap secara mental, sedangkan menurut Vygotsky, pelajaran itu di luar daerah perkembangan pengetahuannya. Dalam hal ini belajar memiliki suatu nilai interaksi sosial untuk membangkitkan minat belajar anak (Suyanto, 2004).

\section{Pendidikan Budaya dan Karakter Bangsa (PBKB)}

Pendidikan budaya dan karakter bangsa itu adalah pendidikan tentang pengembangan nilai-nilai yang didasarkan pada (1) agama, (2) Pancasila sebagai falsafah atau ideologi bangsa Indonesia yang termaktub dalam pembukaan UUD 1945 dan dijabarkan dalam pasal demi pasal di UUD 1945 , (3) budaya yang dijabarkan dalam nilainilai budaya bangsa Indonesia, dan (4) tujuan pendidikan nasional sebagai rumusan kualitas yang harus dimiliki setiap warga negara Indonesia dan dikembangkan oleh berbagai satuan pendidikan di berbagai jenjang dan jalur pendidikan. Nilai-nilai pendidikan budaya dan karakter bangsa yang akan diintegrasikan pada mata pelajaran bahasa Inggris meliputi 18 nilai yaitu (1) religius, (2) jujur, (3) toleransi, (4) disiplin, (5) kerja keras, (6) kreatif, (7) mandiri, (8) demokratis, (9) rasa ingin tahu, (10) semangat kebangsaan,
(11) cinta tanah air, (12) menghargai prestasi, (13) bersahabat atau komunikatif, (14) cinta damai, (15) gemar membaca, (16) peduli lingkungan, (17) peduli sosial, (18) tanggung jawab (Kemendiknas, 2011).

\section{Buku Ajar Interaktif}

Buku ajar adalah buku yang disusun untuk kepentingan proses pembelajaran baik yang bersumber dari hasil-hasil penelitian atau hasil dari sebuah pemikiran tentang kajian bidang tertentu yang kemudian dirumuskan menjadi materi pembelajaran (Direktorat Pendidikan ITB, 2009). Sedangkan materi pembelajaran sebagai isi dari buku ajar berisi pengetahuan, keterampilan, dan sikap yang harus dikuasai peserta didik dalam rangka memenuhi standar kompetensi yang ditetapkan (Depdiknas, 2008). Aspek pengetahuan, sikap, serta keterampilan pada materi pembelajaran mencakup fakta, konsep, prinsip, prosedur serta sikap dan nilai (Depdiknas, 2008).

Sedangkan interaktif mengarah pada sistem multimedia berbasis komputer yang menggunakan jenis isi seperti teks, audio, video, grafik, animasi dan interaktivitas (Sofyan, 2011 dan Mahardika, 2000). Proses aplikasi multimedia pada buku ajar akan dikemas dalam Compact Disk (CD) interaktif untuk meningkatkan karakter siswa SD dengan mengintegrasikan nilai-nilai pendidikan budaya bangsa dalam meningkatkan kemampuan bahasa Inggris siswa SD di kota Malang. Pada saat ini teknolgi infomasi dan komunikasi (TIK) mengalami perkembangan yang pesat dari waktu ke waktu.Perkembangan ini memberikan dampak perubahan pada semua aspek kehidupan termasuk dalam pendidikan dan pembelajaran. Banyak sekolah dalam proses pembelajarannya tidak ingin ketinggalan informasi dan komunikasi sehingga dalam proses pembelajaran memasukkan multimedia interaktif baik pada model pembelajaran dan pengembangan buku ajar.

\section{METODE PENELITIAN}

Untuk menjawab masalah di atas, penelitian ini menggunakan rancangan penelitian pengembangan dan uji coba (experiment). Subjek penelitian terdiri dari subyek ahli dan subyek sasaran. Subyek ahli dalam penelitian ini adalah ahli atau pakar 
pada bidang kurikulum dan materi dan ahli atau pakar multimedia. Sedangkan populasi atau subyek sasaran adalah seluruh siswa kelas VI SDN Dinoyo VI kota Malang yang berjumlah 40 orang. Penelitian ini menggunakan rancangan uji coba sejati (true experimental design) yaitu desain PretestPosttest Control group.

Dalam model ini, terdapat kelompok uji coba (eksperiment group) dan kelompok pengendali (control group) dengan cara pengambilan sampel secara acak (random sampling) yang masing-masing berjumlah 20 orang. Pengamatan dilakukan sebanyak 2 kali yaitu sebelum uji coba (exsperiment) dan sesudah uji coba (eksperiment). Model penelitian ini dapat digambarkan sebagai berikut:

$$
\begin{array}{llll}
R & 01 & X & 02 \\
R & 03 & & 04
\end{array}
$$

$\mathrm{R}=$ Kelompok eksperimen dan control siswa SDN Dinoyo IV Malang dipilih secara acak.

01 dan 03 = Dua kelompok diamati dengan diberikan pretest untuk mengetahui kemampuan awalnya.

02 = Kemampuan siswa dalam kelompok eksperimen setelah menggunakan buku ajar bahasa Inggris interaktif (CD) berbasis nilainilai budaya bangsa

04 = Kemampuan siswa dalam kelompok kontrol setelah menggunakan buku ajar bahasa Inggris manual berbasis nilai-nilai budaya bangsa.

$\mathrm{X}=$ Perlakuan (treatment) berupa penggunaan buku ajar bahasa Inggris interaktif (CD) berbasis nilai-nilai budaya bangsa.

Instrumen pengumpulan data yang digunakan adalah angket, wawancara mendalam, dan tes. Angket dan wawancara digunakan untuk mengumpulkan data tentang efektivitas model buku ajar bahasa Inggris interaktif berbasis nilai-nilai budaya bangsa untuk meningkatkan karakter siswa SD di Kota Malang. Sedangkan tes digunakan untuk melakukan uji coba buku ajar bahasa Inggris interaktif kepada siswa kelas VI SDN Dinoyo IV Malang.

Tes yang telah disusun telah dilakukan uji coba (try out) dan menunjukkan tingkat validitas, reliabilitas yang tinggi dan tingkat kesulitan antara 0,3 - 0,7. Dalam hal ini, uji coba (try out) dilakukan di SDN Lesanpuro IV Sawojajar Malang pada bulan Juni 2014. Sedangkan uji coba produk buku ajar bahasa Inggris interaktif ini berlangsung selama 3 bulan yaitu 12 Agustus 2014 sampai 8 November 2014 kepada siswa kelas VI Dinoyo IV Malang Semester Ganjil pada tahun akademik 2014/2015.

\section{HASIL PENELITIAN}

Ada dua hasil dalam penelitian ini yaitu (1) model buku ajar bahasa Inggris interaktif berbasis nilai-nilai budaya dan karakter bangsa dan (2) efektivitas buku ajar bahasa Inggris interaktif untuk siswa kelas VI SDN Dinoyo kota Malang tersebut. Keduanya akan dipaparkan sebagai berikut.

\section{Model Buku Ajar Bahasa Inggris Interaktif}

Buku ajar bahasa Inggris interaktif ini dimulai dengan pengembangan silabus yang kemudian dijadikan pedoman pengembangan buku ajar. Proses pengembangan buku ajar ini melalui 2 tahap yaitu pengembangan buku ajar bahasa Inggris manual berbasis nilai-nilai budaya bangsa dan kemudian dikembangkan menjadi Compact Disk (CD) bahasa Inggris interaktif berbasis nilai-nilai budaya bangsa. Materi Ajar bahasa Inggris interaktif dengan CD ini dilengkapi dengan (1) gambar-gambar animasi, (2) tulisan-tulisan yang bersifat penjelasan dan perintah, (3) suara rekaman untuk bahan bacaan (reading), pengucapan (pronunciation), dan penjelasan, musik sebagai background $\mathrm{CD}$, dan cara-cara mengoperasikan dengan baik.

Buku ajar bahasa Inggris interaktif yang berisi 3 unit didasarkan pada KTSP 2006 yang melibatkan 4 keterampilan yaitu Reading, Speaking, Listening, dan Writing dan dirancang untuk siswa SD kelas VI semester I. Buku ajar ini berisikan topik dan materi materi yang beragam dan menyenangkan yang mengandung nilai-nilai luhur sesuai dengan budaya dan karakter bangsa Indonesia. Nilai-nilai budaya dan karakter ini bersumber pada (1) agama, (2) Pancasila, (3) budaya nasional, dan (4) tujuan pendidikan nasional yang berjumlah 18 karakter yaitu yaitu (1) religius, (2) jujur, (3) toleransi, (4) disiplin, (5) kerja keras, (6) kreatif, (7) mandiri, (8) demokratis, (9) rasa ingin tahu, (10) semangat kebangsaan, (11) cinta tanah air, (12) menghargai prestasi, (13) bersahabat 
atau komunikatif, (14) cinta damai, (15) gemar membaca, (16) peduli lingkungan, (17) peduli sosial, (18) tanggung jawab. Selain itu, buku ajar ini meliputi komponen bahasa seperti grammar dan vocabulary yang berbasis kontektual yang disesuaikan dengan pola pikir dunia anak SD khususnya kelas VI Semester Ganjil.

\section{Efektivitas Buku Ajar Bahasa Inggris Interaktif}

Pada bagian ini akan dipaparkan tentang hasil uji coba buku ajar bahasa Inggris interaktif berbasis nilai-nilai budaya dan karakter bangsa sehingga efektivitas buku ajar tersebut dapat dijelaskan dengan uji statistik yang digunakan.

Untuk mengetahui efektivitas produk buku ajar bahasa Inggris berbasis nilai-nilai budaya dan karakter bangsa ini, rancangan penelitian eksperimen atau uji coba dilakukan dalam penelitian ini untuk mengetahui apakah buku ajar bahasa Inggris interaktif tersebut memberikan pengaruh signifikan kepada siswa khususnya kelas VI di SDN Dinoyo IV Malang atau tidak.

Untuk melakukan proses ini, desain true experimental design yaitu desain PretestPosttest Control group digunakan. Dalam model ini, terdapat kelompok uji coba (experiment) dan kelompok pengendali (control) dengan cara acak pengembalian sampelnya. Pengamatan dilakukan sebanyak 2 kali yaitu sebelum uji coba (exsperiment) dengan memberikan tes awal (pre-test) dan sesudah uji coba (eksperiment) dengan memberikan tes akhir (post-test).

\section{Uji t (t-test) untuk Mengetahui Kemampuan Awal}

Pada tanggal 17 s.d. 18 Juli 2014, tes awal (pretest) dilakukan dan diberikan kepada 2 kelompok kelas yakni kelas VIA dan VIB SDN Dinoyo IV Malang. Tujuan dari pretest ini adalah untuk mengetahui kemampuan awal kedua kelompok tersebut. Hasil analisis tes awal (pretest) ini diharapkan adanya kesamaan kemampuan atau tidak ada perbedaan kemampuan antara kelompok uji coba (experiment group) dan kelompok pengendali (control group). Dengan ini, perlakuan (treatment) dapat diberikan pada kelompok uji coba (experiment group) sehingga pengaruh buku ajar bahasa Inggris interaktif yang diberikan kepada siswa kelas VIB dapat diketahui pengaruh atau tingkat efektivitasnya ketika dibandingkan dengan siswa kelas VIA yang hanya menggunakan buku ajar bahasa Inggris manual (noninteraktif).

Berdasarkan keterangan di atas, dari dua hipotesis yang diajukan dalam penelitian ini yaitu $\mathrm{H}_{0}$ dan Ha. Hipotesis $\mathrm{Nol}\left(\mathrm{H}_{0}\right)$ dan Hipotesis Alternatif ( $\mathrm{Ha}$ ), maka $\mathrm{H}_{0}$ diharapkan yaitu "Tidak ada perbedaan antara siswa kelas VIB SDN Dinoyo IV Malang yang diajar dengan menggunakan buku ajar bahasa Inggris interaktif berbasis nilai-nilai budaya bangsa dengan siswa kelas VIA yang diajar dengan menggunakan buku ajar bahasa Inggris manual berbasis nilai-nilai budaya bangsa". Setelah tes awal ini diujikan kemudian dianalisis hasilnya dan dibandingkan antara kelompok uji coba (experiment group) dan kelompok pengendali (control group) dengan menggunakan uji-t sebagai berikut:

$$
\mathrm{Uji}-\mathrm{t}=\frac{\text { Rerata } X 1-\text { Rerata } X 2}{\sqrt{\left[\frac{\mathrm{Jk} 1+\mathrm{Jk} 2}{\mathrm{~N} 1+\mathrm{N} 2-2}\right]\left[\frac{1}{N 1}+\frac{1}{N 2}\right]}}
$$

$$
\text { Uji-t }=\frac{59,95-58,5}{\left.\sqrt{\left[\frac{3.134,95+6.479}{20+20-2}\right]}\right]\left[\frac{1}{20}+\frac{1}{20}\right]}
$$

$t_{\text {hasil }}=0,299$

Df $($ degree of freedom $)=(\mathrm{N} 1+\mathrm{N} 2)-2=40-2=$ 38 maka:

Taraf signifikan $1 \% t_{\text {tabel }}=1,697$ (dua ekor/arah)

Taraf signifikan $5 \% t_{\text {tabel }}=2,042$ (dua ekor/arah)

Hasil analisis di atas dapat disimpulkan sebagai berikut:

$\mathrm{t}_{\text {hasil }}<\mathrm{t}$ tabel

$0,299<1,697$ taraf signifikan $1 \%$

$0,299<2,042$ taraf signifikan $5 \%$

Dengan demikian, hasil ini menunjukkan bahwa hipotesis $\mathrm{H}_{0}$ diterima yang menyatakan "Tidak ada perbedaan dalam kemampuan siswa yang diajar dengan menggunakan buku ajar bahasa Inggris interaktif berbasis nilai-nilai budaya bangsa dalam hal ini adalah siswa kelas VIB dengan 
mereka yang yang diajar dengan menggunakan buku ajar bahasa Inggris manual berbasis nilai-nilai budaya bangsa yang dalam hal ini adalah kelas VIA", sedangkan Ha yang menyatakan "Terdapat perbedaan antara siswa kelas VIB SDN Dinoyo IV Malang yang diajar dengan menggunakan buku ajar bahasa Inggris interaktif berbasis nilai-nilai budaya bangsa dengan siswa kelas VIA yang yang diajar dengan menggunakan buku ajar bahasa Inggris manual berbasis nilai-nilai budaya bangsa" itu ditolak.

\section{Pengujian Hipotesis}

Pada bagian ini akan dilakukan penghitungan hasil akhir dengan tes akhir (posttest) yang diberikan kepada 2 kelompok yaitu kelompok eksperimen (experiment group) yang diberikan perlakuan (treatment) penggunaan buku ajar bahasa Inggris interaktif (CD) dan kelompok kontrol yang diberikan hanya buku ajar bahasa Inggris manual selama 3 bulan bulan Agustus, September, dan Oktober 2014. Berdasarkan analisis statistik, ada dua hipotesis yang diajukan dalam penelitian ini yaitu $\mathrm{H}_{0}$ dan $\mathrm{Ha}$. Hipotesis Nol $\left(\mathrm{H}_{0}\right)$ dan Hipotesis Alternatif (Ha) dalam penelitian ini dapat dinyatakan sebagai berikut. $\mathrm{H}_{0}$ : "Tidak ada perbedaan antara siswa kelas VIA SDN Dinoyo IV Malang yang diajar dengan menggunakan buku ajar bahasa Inggris interaktif berbasis nilai-nilai budaya bangsa dengan mereka yang diajar dengan menggunakan buku ajar bahasa Inggris manual berbasis nilai-nilai budaya bangsa". Sedangkan Ha: "Siswa kelas VIB SDN Dinoyo IV Malang yang diajar dengan menggunakan buku ajar bahasa Inggris interaktif berbasis nilai-nilai budaya bangsa memiliki kemampuan bahasa Inggris yang lebih baik daripada siswa kelas VIA yang diajar dengan menggunakan buku ajar bahasa Inggris manual berbasis nilai-nilai budaya bangsa".

Setelah tes akhir (posttest) diberikan dan dianalisis dan dibandingkan hasilnya antara kelompok uji coba (experiment group) dan kelompok pengendali (control group) dengan menggunakan uji-t sebagai berikut:

$\mathrm{Uji}-\mathrm{t}=\frac{\operatorname{Rerata} X 1-\text { Rerata } X 2}{\sqrt{\left[\frac{\mathrm{Jk} 1+\mathrm{Jk} 2}{\mathrm{~N} 1+\mathrm{N} 2-2}\right]\left[\frac{1}{N 1}+\frac{1}{N 2}\right]}}$
$\mathrm{Uji}-\mathrm{t}=\frac{83,2-59,85}{\sqrt{\left[\frac{1.331,2+4.556,55}{20+20-2}\right]\left[\frac{1}{20}+\frac{1}{20}\right]}}$

$t_{\text {hasil }}=5,93$

Df $($ degree of freedom $)=(\mathrm{N} 1+\mathrm{N} 2)-2=40-2$

= 38 maka:

Taraf signifikan $1 \% t_{\text {tabel }}=1,310$ (satu ekor/arah)

Taraf signifikan $5 \% \quad t_{\text {tabel }}=1,697$ (satu ekor/arah)

Berdasarkan hasil analisis melalui proses statistik di atas, menunjukkan bahwa $\mathrm{t}$ hasil $(5,93)$ terbukti lebih besar daripada $t$ tabel $(1,310)$ pada signifikan 0,01 dan $(1,697)$ pada taraf signifikan 0,05 dengan satu ekor/arah (one-tail/one directional). Ini berarti bahwa Ha yang menyatakan "Siswa kelas VIB SDN Dinoyo IV Malang yang diajar dengan menggunakan buku ajar bahasa Inggris interaktif berbasis nilai-nilai budaya bangsa memiliki kemampuan bahasa Inggris yang lebih baik daripada siswa kelas VIA yang diajar dengan menggunakan buku ajar bahasa Inggris manual berbasis nilai-nilai budaya bangsa" diterima, sedangkan $\mathrm{H}_{0}$ yang menyatakan "Tidak ada perbedaan antara siswa kelas VIA SDN Dinoyo IV Malang yang diajar dengan menggunakan buku ajar bahasa Inggris interaktif berbasis nilai-nilai budaya bangsa dengan mereka yang diajar dengan menggunakan buku ajar bahasa Inggris manual berbasis nilai-nilai budaya bangsa" ditolak.

\section{PEMBAHASAN}

Pada bagian ini akan dibahas hasil penelitian secara satu persatu di bawah ini berkaitan dengan model buku ajar bahasa Inggris interaktif dan efektivitas buku ajar tersebut dalam mempengaruhi kemampuan bahasa Inggris siswa kelas VI SDN Dinoyo IV Malang.

\section{Model Buku Ajar Bahasa Inggris Interaktif}

Mekanisme pengembangan buku ajar bahasa Inggris interaktif ini diawali dengan penyusunan silabus bahasa Inggris berdasarkan KTSP 2006. Proses pengembangan ini dimulai dengan mempelajari Standar Isi (SI) dan Standar Kompetensi Lulusan (SKL) khususnya untuk siswa kelas VI SD. Dengan mempelajari dan menganalisis Standar Kompetensi (SK) dan 
Kompetensi Dasar (KD), indikator-indikator dapat dikembangkan dengan aneka ragam materi yang disesuaikan dengan tingkat perkembangan pola pikir dan mental siswa khususnya siswa kelas VI.

Pengembangan materi ini dikemas dan diintegrasikan dengan nilai-nilai budaya dan karakter bangsa yang telah disosialisasikan oleh Kementerian Pendidikan Nasional (Kemendiknas) pada tahun 2010 lewat sebuah buku pedoman yang berjudul "Pengembangan Pendidikan Budaya Karakter Bangsa". Selain itu, materi pembelajaran sebagai isi dari buku ajar bahasa Inggris interaktif ini berisi pengetahuan, keterampilan, dan sikap yang harus dikuasai peserta didik dalam rangka memenuhi standar kompetensi yang ditetapkan (Depdiknas, 2008). Aspek-aspek ini telah mencakup fakta, konsep, prinsip, prosedur serta sikap dan nilai (Depdiknas, 2008 dan Peraturan Mendikbud, 2013). Oleh karena itu, Materi ajar pada buku ini telah memenuhi syarat dalam pengembangan 4 kompetensi siswa menurut kurikulum 2013 yaitu kompetensi (1) sikap spiritual, (2) sikap soial, (3) pengetahuan, dan (4) keterampilan (Peraturan Mendikbud, 2013).

Model buku ajar ini telah mengalami penyempurnaan yang dilakukan (1) sebelum diujicobakan, (2) ketika diujicobakan, dan (3) setelah diujicobakan. Dengan demikian, buku ajar bahasa Inggris interaktif berbasis nilainilai budaya bangsa telah siap digunakan secara luas sesuai dengan permintaan para guru khususnya di Kota Malang Jawa Timur (Marsuki, 2013).

\section{Efektivitas Buku Ajar Bahasa Inggris Interaktif}

Di atas telah dipaparkan hasil analisis yang menjadi temuan tentang efektivitas dan pengaruh dari buku ajar bahasa Inggris interaktif berbasis nilai-nilai budaya bangsa. Temuan ini menunjukkan tingkat efektivitas dan pengaruh yang signifikan dalam meningkatkan prestasi dan kemampuan bahasa Inggris bagi siswa SD kelas VI SDN Dinoyo VI Malang.

Sesuai dengan prosedur, sebelum diberikan perlakuan (treatment), pengetahuan tentang kemampuan awal siswa pada 2 kelompok yaitu kelompok uji coba (experiment group) dan kelompok pengendali (control group) telah dilakukan dengan memberikan tes awal (pretest) dan hasilnya dengan menggunakan uji statistic diketahui bahwa kedua kelompok tersebut memiliki kemampuan yang sama. Selanjutnya pemberian perlakuan (treatment) dalam hal ini adalah uji coba penggunaan buku ajar bahasa Inggris interaktif berbasis nilai-nilai budaya bangsa kepada siswa kelas VIB dan penggunaan buku ajar bahasa Inggris manual kepada siswa kelas VIA SDN Dinoyo IV Malang dilakukan selama 3 bulan mulai tanggal 12 Agustus hingga 8 November 2014. Selama uji coba ini berbagai penyempurnaan buku ajar interaktif dilakukan atas dasar masukanmasukan dari ahli khususnya ahli multimedia dan juga dari kepala sekolah dan guru bahasa Inggris SDN Dinoyo VI Malang. Pemberian perlakuan ini kemudian diakhiri dengan memberikan tes akhir (posttest) untuk mengetahui pengaruh dan tingkat efektivitas buku ajar tersebut.

Berdasarkan hasil analisis statistik dengan uji-t, ditemukan sebagai berikut:

$\mathrm{Uji}-\mathrm{t}=\frac{\text { Rerata } X 1-\text { Rerata } X 2}{\sqrt{\left[\frac{\mathrm{Jk} 1+\mathrm{Jk} 2}{\mathrm{~N} 1+\mathrm{N} 2-2}\right]\left[\frac{1}{N 1}+\frac{1}{N 2}\right]}}$

$\mathrm{Uji}-\mathrm{t}=\frac{83,2-59,85}{\left.\sqrt{\left[\frac{1.331,2+4.556,55}{20+20-2}\right.}\right]\left[\frac{1}{20}+\frac{1}{20}\right]}$

$t_{\text {hasil }}=\mathbf{5 , 9 3}$

Df $($ degree of freedom $)=(\mathrm{N} 1+\mathrm{N} 2)-2=40-2$ = 38 maka:

Taraf signifikan $1 \% \quad t_{\text {tabel }}=1,310$ (satu ekor/arah)

Taraf signifikan $5 \% \quad t_{\text {tabel }}=1,697$ (satu ekor/arah)

Berdasarkan hasil analisis melalui proses statistik di atas, menunjukkan bahwa $\mathrm{t}$ hasil $(5,93)$ terbukti lebih besar daripada $t$ tabel $(1,310)$ pada taraf signifikan 0,01 dan $(1,697)$ pada taraf signifikan 0,05 dengan satu ekor/arah (one-tail/one directional). Ini berarti bahwa Hipotesis alternatif (Ha) diterima, sedangkan $\mathrm{H}_{0}$ ditolak. Tingkat keefektivan ini juga didukung oleh hasil angket siswa dan wawancara guru bahasa Inggris yang menyatakan senang belajar dan mengajar bahasa Inggris dengan menggunakan buku ajar bahasa Inggris interaktif berbasis nilai-nilai budaya dan karakter bangsa ini. 
Dengan diterimanya hipotesis alternatif (Ha), maka penggunaan buku ajar bahasa Inggris interaktif berbasis nilai-nilai budaya bangsa adalah efektif bahkan sangat efektif dari nilai $t$ hasil yang diperoleh sangat tinggi yaitu $(5,93)$ yang jauh melebihi $t$ tabel $(1,310)$ pada signifikan 0,01 . Begitu juga, pada taraf signifikan 0,05 dan nilai $t$ hasil jauh melebihi tabel yaitu pada angka 1,697. Ini berarti tingkat keefektivan buku ajar dalam meningkatkan kemampuan dan prestasi bahasa Inggris siswa SD, khususnya siswa kelas VI SDN Dinoyo IV Malang.

\section{SIMPULAN}

Hasil atau temuan dalam penelitian ini yang meliputi (1) model buku ajar bahasa Inggris interaktif dan (2) efektivtas buku ajar bahasa Inggris interaktif berbasis nilai-nilai budaya bangsa dapat disimpulkan sebagai berikut:

\section{Model Buku Ajar Bahasa Inggris Interaktif}

Buku ajar bahasa Inggris interaktif ini terdiri dari 2 (dua) cakupan utama yaitu cakupan isi atau materi dan cakupan sistem interaktif yang berbasis multimedia yang dilengkapi dengan sistem animasi yaitu sistem berbasis komputer yang menggunakan teks, audio, video, grafik, animasi dan interaktivitas dalam pembelajaran bahasa Inggris. Buku ajar ini berisi 3 unit untuk siswa kelas VI Semester Ganjil. Materi pembelajaran meliputi pengetahuan, keterampilan, dan sikap yang harus dikuasai peserta didik dalam rangka memenuhi standar kompetensi yang mencakup fakta, konsep, prinsip, prosedur serta sikap dan nilai yang didasarkan pada
KTSP 2006 yang melibatkan 4 keterampilan yaitu Reading, Speaking, Listening, dan Writing dan dirancang untuk siswa SD kelas VI semester I. Buku ajar ini berisikan topik dan materi materi yang beragam dan menyenangkan yang mengandung nilai-nilai luhur sesuai dengan budaya dan karakter bangsa Indonesia. Nilai-nilai budaya dan karakter ini bersumber pada (1) agama, (2) Pancasila, (3) budaya nasional, dan (4) tujuan pendidikan nasional yang berjumlah 18 karakter.

\section{Efektivitas Buku Ajar Bahasa Inggris Interaktif}

Menurut hasil analisis uji statistik, dapat disimpulkan bahwa $t_{\text {hasil }}(5,93)$ terbukti lebih besar daripada $t$ tabel $(1,310)$ pada taraf signifikan 0,01 dan $(1,697)$ pada taraf signifikan 0,05 dengan satu ekor/arah (onetail/one directional). Ini berarti bahwa $\mathrm{Ha}$ yang menyatakan "Siswa kelas VIB SDN Dinoyo IV Malang yang diajar dengan menggunakan buku ajar bahasa Inggris interaktif berbasis nilai-nilai budaya bangsa memiliki kemampuan bahasa Inggris lebih baik daripada siswa kelas VIA yang diajar dengan menggunakan buku ajar bahasa Inggris manual berbasis nilai-nilai budaya bangsa" diterima, sedangkan $\mathrm{H}_{0}$ yang menyatakan sebaliknya ditolak.

Dengan diterimanya hipotesis alternatif (Ha), maka penggunaan buku ajar bahasa Inggris interaktif berbasis nilai-nilai budaya bangsa adalah efektif bahkan sangat efektif dari nilai $t$ hasil yang diperoleh sangat tinggi yaitu $(5,93)$ yang jauh melebihi $t$ tabel $(1,310)$ pada signifikan 0,01.

\section{DAFTAR PUSTAKA}

Arikunto, S. (2002). Prosedur Penelitian: Suatu Pendekatan Praktik. Jakarta: Rineka Cipta.

Akbar, S. (2011). Revitalisasi Pendidikan Karakter di Sekolah Dasar. Pidato Pengukuhan Guru Besar. Universitas Negeri Malang

BSNP. (2006). Panduan Penyusunan Kurikulum Tingkat Satuan Pendidikan Jenjang Pendidikan Dasar dan Menengah. Jakarta: Departemen Pendidikan Dasar.

Darmiyati, Z. (2003). Teknik Menulis Buku Ajar.Bahan Pelatihan Penulisan Buku Ajar. Jakarta: Dikti Depdiknas. Depdiknas (2006).Pengembangan Model Pembelajaran Yang Efektif. Yokyakarta: Program Pascasarjana.

Degeng, N. S. (2001). Pedoman Penulisan Bahan Ajar. Malang: LP3 Universitas Negeri Malang. 
Departemen Pendidikan Nasional. (2002). Pendekatan Kontekstual: Contextual Teaching and Learning. Jakarta: Direktorat PLP.

Departemen Pendidikan Nasional. 2008. Panduan Pengembangan Materi Pembelajaran. Direktorat Jenderal Manajemen Pendidikan Dasar dan Menengah. Direktorat Pembinaan Sekolah Menengah Atas.

Kementerian Pendidikan Nasional. (2010). Pengembangan Pendidikan Budaya Karakter Bangsa. Badan Penelitian Pengembangan Pusat Kurikulum.

Kementerian Pendidikan Nasional. 2011. Panduan Pelaksanaan Pendidikan Karakter. Badan Penelitian dan Pengembangan Pusat Kurikulum dan Perbukuan.

Mahardika, I. N. (2009). Pengembangan Multimedia dalam Pembelajaran Kosakata Bahasa Inggris di $S D$. http://mardikanyom.tripod.com/Multimedia.pdf

Marsuki, Yahmun, dan Efendy, B.A. (2013). Peningkatan Karakter Siswa Sekolah Dasar (SD) Melalui Pengembangan Buku Ajar Bahasa Inggris Interaktif Berbasis Nilai-Nilai Budaya Bangsa di Kota Malang. Penelitian Desentralisasi Hibah Bersaing. Dikti Kemendikbud.

Nuh, M. (2009). Pendidikan Budaya Karakter. Balitbang

Peraturan Menteri Pendidikan Nasional No. 22 Tahun 2006 tentang Standar Isi untuk Satuan Pendidikan Dasar dan Menengah. Jakarta: Depdiknas

Peraturan Menteri Pendidikan Nasional No. 65, 66, 67, 68, 69, 70, 71 Tahun 2013 tentang Kurikulum 2013. Jakarta: Depdikbud

Sofyan, H. (2011). Aplikasi Interaktif Pengenalan Bahasa Inggris untuk Taman Kanak-Kanak Menggunakan Macromedia Flash 8. Tulisan Ilmiah. Universitas Gunadarma.

Supina dan Parmi I.T. (2011). Pengembangan Pendidikan Budaya dan Karakter Bangsa melalui Pembelajaran Matematika di SD. Badan Pengembangan Sumber daya Manusia Pendidikan dan Penjaminan Mutu Pendidikan.Kementerian Pendidikan Nasional.

Suyanto, K. K. E. (1997). Teaching English to Young Learners in Indonesia. In E. Sadtono (ed.). The Development of TEFL in Indonesia. Malang: Penerbit IKIP Malang

Suyanto, K. K. E. (2004). Pengajaran Bahasa Inggris di Sekolah Dasar: Kebijakan, Implementasi, dan Kenyataan. Pidato Pengukuhan Jabatan Guru Besar Bidang Metodologi. Pengajaran Bahasa Inggris Pada Fakultas Satra. Senat Universitas Negeri Malang.

Undang-undang Republik Indonesia No. 20 Tahun 2003 Tentang Sistem Pendidikan Nasional. Bandung: Citra Umbara. 